\title{
EVALUASI PELAKSANAAN SISTEM AKUNTANSI BELANJA PADA DINAS SOSIAL TENAGA KERJA DAN TRANSMIGRASI KABUPATEN MINAHASA SELATAN SESUAI PP NO 71 TAHUN 2010
}

\author{
Marsella Lasut $^{1}$, Jenny Morasa ${ }^{2}$, Lidia M. Mawikere $^{3}$ \\ 1,2,3 Jurusan Akuntansi, Fakultas Ekonomi dan Bisnis, Universitas Sam Ratulangi, Jl. Kampus Bahu, Manado, \\ 95115, Indonesia \\ E-mail : mlasut88@gmail.com
}

\begin{abstract}
Government Regulation No. 71 Year 2010 about government accounting standards, shopping is is recognized when an expense is made from the State / Region general account. Shopping accounting is structured to meet accountability requirements in accordance with the provisions. This study aims to Evaluate the Implementation of Shopping Accounting System at office of Social, Manpower, and Transmigration of District South Minahasa Province in accordance with Regulation No.71 Year 2010. The object of office of Social, Manpower, and Transmigration of District South Minahasa. The method used in this research is qualitative descriptive analytical method. The result of the Social Service Research of Manpower and Transmigration is always guided by the existing regulations and in the Implementation of Shopping Accounting System, has applied or has been in accordance with Government Regulation No. 71 of 2010 on Government Accounting Standards.
\end{abstract}

Keywords : Implementation, System, Accounting, Shopping

\section{PENDAHULUAN}

Belanja Daerah merupakan bagian penting dalam sistem administrasi keuangan daerah, karena hal ini terkait dengan Sistem Pertanggungjawaban Keuangan Negara dan Pemerintah Daerah khususnya. Menurut pasal 289 dari Peraturan Menteri Dalam Negeri Nomor 13 Tahun 2006 tentang Pedoman Pengelolaan Keuangan Daerah, untuk tingkat pemerintahan Kabupaten/Kota, Kepala Satuan Kerja Pengelola Keuangan Daerah selaku pengguna anggaran wajib menyelenggarakan akuntansi atas semua transaksi keuangan yang meliputi aset, utang dan ekuitas dana yang berada dibawah tanggung-jawabnya. Untuk tingkat kantor dan/atau satuan kerja, Kepala Satuan Kerja Perangkat Daerah dapat mendelegasikan kepada PPK-SKPD untuk bertanggungjawab atas penyelenggaraan akuntansi terhadap Penggunaan Anggaran di lingkungan Kantor atau SKPD terkait.

Permendagri No 13 Tahun 2006 Menjelaskan bahwa Belanja Daerah adalah Semua Kewajiban Daerah yang diakui sebagai pengurang nilai kekayaan bersih. Belanja dibagi menjadi 2 Kelompok yaitu Belanja Tidak Langsung dan Belanja Langsung. Belanja Langsung dan Belanja Tidak Langsung merupakan pengeluaran kas yang kegiatannya paling sering digunakan untuk melakukan berbagai macam pembiyaan. Belanja Langsung merupakan belanja yang dianggarkan terkait secara langsung dengan program dan kegiatan. Sedangkan Belanja Tidak Langsung merupakan Belanja yang tidak terkait langsung dengan pelaksanaan program/kegiatan.

Menteri Dalam Negeri telah menetapkan Permendagri Nomor 64 Tahun 2013 tentang Penerapan Standar Akuntansi Pemerintahan Berbasis Akrual Pada Pemerintah Daerah. Terbitnya Peraturan Menteri Dalam Negeri tersebut merupakan tindak lanjut dari pasal 7 ayat 3 PP Nomor 71 Tahun 2010 tentang SAP. Peraturan menteri dalam negeri tersebut akan 
menjadi panduan bagi pemerintah daerah dalam menyusun kebijakan akuntansi Pemerintah Daerah dan Sistem Akuntansi Pemerintah Daerah (SAPD), termasuk Bagan Akun Standar (BAS), yang selanjutnya ditetapkan dalam suatu Peraturan Kepala Daerah. Sesuai pasal 10 ayat 1 Permendagri tersebut, Peraturan Kepala Daerah tentang Kebijakan Akuntansi dan SAPD tersebut harus sudah ditetapkan paling lambat pada tanggal 31 Mei 2014. Sesuai PP Nomor 71 tahun 2010, penerapan SAP Berbasis Akrual pada Pemerintah Daerah harus dilaksanakan mulai tahun anggaran 2015.

Dinas Sosial Tenaga Kerja dan Transmigras Minahasa Selatan salah satu Satuan Kerja Perangkat Daerah (SKPD) dari segi pelaksanaan anggaran, pendapatan, dan belanja lebih dominan dari segi penganggarannya adalah komponen belanja dari pada pendapatan. Pelaksanaan belanja dimulai dari penganggaran sampai pengeluaran. Dinas Sosial Tenaga Kerja dan Transmigrasi Kabupaten Minahasa Selatan dalam Sistem Pelaksanaan Akuntansi Belanja ada Peraturan yang ditetapkan dalam PP Nomor 71 Tahun 2010.maka penulis tertarik untuk melakukan evaluasi tentang akuntansi belanja pada Dinas Sosial Tenaga Kerja Dan Transmigrasi Kabupaten Minahasa Selatan. Dengan alasan tersebut penulis memilih judul skripsi yaitu "Evaluasi Pelaksanaan Sistem Akuntansi Belanja Pada Dinas Sosial Tenaga Kerja Dan Transmigrasi Kabupaten Minahasa Selatan Berdasarkan PP Nomor 71 Tahun 2010 ."

\section{TINJAUAN PUSTAKA}

\subsection{Konsep Akuntansi}

Peraturan Pemerintah No. 71 tahun 2010 tentang Standar Akuntansi Pemerintahan pasal 1 ayat 2 Akuntansi adalah proses identifikasi, pencatatan, pengukuran, pengklasifikasian, pengikhtisaran transaksi dan kejadian keuangan, penyajian laporan serta penginterprestasian atas hasilnya. Saat ini PP No. 24 tahun 2005 telah direvisi oleh Pemerintah dengan dikeluarkannya PP No. 71 tahun 2010. Definisi lain menurut Permendagri Nomor 64 Tahun 2013 dalam pasal 1 ayat 2 menjelaskan bahwa akuntansi adalah proses identifikasi, pencatatan, pengukuran, pengklasifikasian, pengikhtisaran transaksi dan kejadian keuangan, penyajian laporan serta penginterprestasian atas hasilnya.

Akuntansi pada dasarnya akan menghasilkan informasi dari sebuah sistem akuntansi yang ada di dalam sebuah entitas atau organisasi bisnis yang disebut dengan informasi akuntansi yang akan dimanfaatkan oleh pengguna seperti masyarakat umum, masyarakat interlektual (termasuk didalamnya mahasiswa atau peneliti) dan para pengambil keputusan bisnis dalam organisasi (pontoh, 2013:2).

\subsection{Akuntansi Sektor Publik}

Akuntansi Sektor Publik dapat didefinisikan sebagai aktivitas jasa yang terdiri dari mencatat, mengklasifikasikan dan melaporkan kejadian atau transaksi ekonomi yang akhirnya akan menghasilkan suatu informasi keuangan yang akan dibutuhkan oleh pihak-pihak tertentu untuk pengambilan keputusan yang diterapkan pada pengelolaan dana publik di lembagalembaga tinggi Negara dan departemen-departemen dibawahnya. Wiratna, (2015:1).

Dari sudut pandang ilmu ekonomi, sektor publik sering didefinisikan sebagai suatu entitas yang aktivitasnya berhubungan dengan penyediaan barang dan jasa untuk memenuhi kebutuhan dan hak publik. Sektor publik adalah seluruh kegiatan yang dibiayai oleh pemerintah baik dari hasil pungutan pajak maupun penerimaan Negara lain-lain, termasuk yang bersumber dari utang.Jenis kegiatan yang dilakukan adalah penyediaan pelayanan yang bersifat monopolistik, baik yang dipandang sebagai bagian dari kebutuhan masyarakat. Dari segi kepemilikan, sector public adalah segala sesuatu yang dimiliki oleh umum atau masyarakat, bukan oleh pemegang saham atau sekelompok orang (kurniawan,2016). Dalam 
perkembangannya, sektor publik sangat berperan dalam peraturan barang publik sehingga dapat didistribusikan kepada segenap masyarakat secara adil dan merata.

\subsection{Sistem Akuntansi Pemerintah Daerah}

Sistem Akuntansi Pemerintahan yang termuat dalam Peraturan Pemerintah No. 71 Tahun 2010 adalah rangkaian sistematik dari prosedur, penyelenggara, peralatan, dan elemen lain untuk mewujudkan fungsi akuntansi sejak analis transaksi sampai dengan pelaporan keuangan di lingkungan organisasi pemerintah. Sementara itu, dalam Peraturan Menteri Dalam Negeri No. 21 Tahun 2011, sistem akuntansi keuangan daerah didefinisikan sebagai serangkaian prosedur mulai dari proses pengumpulan data, pencatatan, pengikhtisaran, sampai dengan pelaporan keuangan dalam rangka pertanggungjawaban pelaksana APBD yang dapat dilakukan secara manual atau menggunakan aplikasi komputer.

SAP dinyatakan dalam bentuk Pernyataan Standar Akuntansi Pemerintahan (PSAP) yang dilengkapi dengan pengantar Standar AKuntansi Pemerintahan. PSAP disusun dan dikembangkan oleh Komite Standar AKuntansi Pemerintahan (KSAP) dengan mengacu pada Kerangka Konseptual Akuntansi Pemerintahan Tanjung (2012:20). SAP ini terdiri atas sebuah kerangka konseptual dan sebuah pernyataan yaitu sebagai berikut :

1. PSAP 01 Penyajian Laporan Keuangan

2. PSAP 02 Laporan Realisasi Anggaran

3. PSAP 03 Laporan Aliran Kas

4. PSAP 04 Catatan atas Laporan Keuangan

5. PSAP 05 Akuntansi Persediaan

6. PSAP 06 Akuntansi Investasi

7. PSAP 07 Akuntansi Aset Tetap

8. PSAP 08 Akuntansi Konstruksi dalam Pengerjaan

9. PSAP 09 Akuntansi Kewajiban

10. PSAP 10 Koreksi Kesalahan

11. PSAP 11 Laporan Keuangan Konsolidasian

12. PSAP 12 Laporan Operasional

Standar Akuntansi Pemerintahan di Indonesia dikeluarkan oleh Komite Standar Akuntansi Pemerintahan (KSAP). Dalam sejarah perkembangan Standar Akuntansi Pemerintahan di Indonesia terdapat dua produk perundangan terkait standar akuntansi pemerintahan, yaitu Peraturan Pemerintah (PP) No. 24 Tahun 2005 dan PP No. 71 Tahun 2010 tentang standar Akuntansi Pemerintahan (SAP). PP No. 71 Tahun 2010 merupakan pengganti dari peraturan standar akuntansi lama dalam PP No. 24 Tahun 2005. PP No. 24 Tahun 2005 menggunakan basis pencatatan kas menuju akrual (cash towards accrual) sedangkan PP No. 71 Tahun 2010 menggunakan basis pencatatan akrual penuh (full accrual).

\subsection{Konsep Akuntansi Belanja}

PSAP No.2 Paragraf 7, mengatur bahwa belanja daerah adalah semua pengeluaran dari Rekening Kas Umum Negara/Daerah yang mengurangi saldo Anggaran lebih dalam periode tahun anggaran bersangkutan yang tidak akan diperoleh pembayarannya kembali oleh pemerintah. Sedangkan menurut Peraturan Menteri Dalam Negeri Nomor 13 Tahun 2006 tentang Pedoman Pengelolaan Keuangan Daerah sebagaimana telah diubah dengan Permendagri Nomor 59 tahun 2007 dan perubahan kedua dengan Peraturan Menteri Dalam Negeri Nomor 21 Tahun 2011 tentang Perubahan kedua. Belanja Daerah didefenisikan 
sebagai kewajiban pemerintah daerah yang diakui sebagai pengurang nilai kekayaan bersih. Istilah belanja terdapat dalam laporan realisasi anggaran, karena dalam penyusunan laporan realisasi anggaran masih menggunakan basis kas. Menurut IASC framework yang dikutip oleh kurniawan (2016) biaya atau belanja daerah merupakan penurunan dalam bentuk arus kas keluar, atau deplasi asset, atau terjadinya hutang yang mengakibatkan berkurangnya ekuitas dana.

1. Klasifikasi Belanja Menurut PP No 71 tahun 2010 tentang Standar Akuntansi Pemerintahan

Pada Paragraf 34 PSAP Nomor 02 PP 71 tahun 2010 dijelaskan bahwa Belanja diklasifikasikan menurut Ekonomi (jenis belanja), dan fungsi. Klasifikasi ekonomi adalah pengelompokkan belanja yang didasarkan pada jenis belanja untuk melaksanakan suatu aktivitas. Klasifikasi ekonomi untuk pemerintah daerah meliputi Belanja Pegawai, Belanja Barang, Belanja Modal, Bunga, Subsidi, Hibah, Bantuan Sosial, dan Belanja tak terduga.Belanja Operasi adalah pengeluaran anggaran kegiatan sehari-hari pemerintah pusat/daerah yang memeberi manfaat lebih dari satu periode akuntansi. Belanja Operasi antara lain meliputi Belanja Pegawai, Belanja Barang, bunga, Subsidi, Hibah, Bantuan Sosial. Belanja Modal adalah pengeluaran untuk perolehan aset tetap dan aset lainnya yang member manfaat lebih dari satu periode akuntansi.Belanja Modal meliputi belanja modal untuk perolehan Tanah, Gedung, dan Bangunan, Peralatan, dan Aset tak Berwujud. Belanja Lain-lain tak Terduga adalah pengeluaran anggaran untuk kegiatan yang sifatnya tidak bias dan tidak diharapkan berulang seperti penanggulangan bencana alam, bencana sosial, dan pengeluaran tidak terduga lainya yang sangat diperlukan dalam rangka penyelenggaraan Kewenangan Pemerintah Pusat/Daerah

2. Klasifikasian Belanja Daerah Bedasarakan Permendagri No 21 Tahun 2011

Klasifikasian belanja daerah bedasarakan Permendagri No 21 tahun 2011 tentang pedoman Pengeluaran Keuangan Daerah dibagi atas:

Klasifikasi Belanja menurut Fungsi.

Belanja menurut fungsi adalah klasifikasi yang didasarkan pada fungsi-fungsi utama pemerintah dalam memberikan pelayanan kepada masyarakat serta untuk meningkatakan keselarasan dan keterpaduan pengelolaan keuangan negara yang terdiri dari Pelayanan Umum, ketertiban dan ketentraman, ekonomi, lingkungan hidup, perumahan dan fasilitas umum, kesehatan, pariwisata, dan budaya, pendidikan dan perkindungan sosial.

Klasifikasi Belanja menurut Urusan Pemerintah.

Klasifikasi Belanja Urusan Pemerintah terdiri dari belanja wajib dan belanja urusan pilihan. Belanja penyelengaraan urusan wajib di prioritaskan untuk melindungi dan meningkatkan kualitas kehidupan masyarakat dalam upaya memenuhi kewajiban daerah yang diwujudkan dalam bentuk peningkatan pelayanan dasar, pendidikan, kesehatan, fasilitas sosial dan fasilitas umum yang layak serta mengembangkan sistem jaminan sosial. Belanja menurut urusan peilihan terdiri daribidang pertanian, kebutuhan energy dan sumber daya mineral, pariwisata kelauta dan perikanan perdagangan, perindustrian, dan transmigrasi.

\subsection{Penelitian Terdahulu}

Hardianti Suratinoyo (2016), Evaluasi Penerapan akuntansi belanja pada dinas kebudayaan dan pariwisata kabupaten minahasa selatan, tujuannya untuk untuk mengevaluasi penerapan akuntansi belanja berdasarkan peraturan pemerintah no.71 tahun 2010pada Dinas Pekerjaan Umum Kabupaten Minahasa telah berpedoman pada Standar Akuntansi Pemerintahan. Metode Penelitian yang digunakan adalah deskriptif.Hasil dari penelitian 
penerapan akuntansi belanja pada dinas kebudayaan dan pariwisata kabupaten minahasa setan sudah sesuai peraturan pemerintah no.71 tahun 2010. Terdapat persamaan dan perbedaan dengan penelitian yang dilakukan. Persamaannya yaitu metode penelitian dan perbedaan yaitu pada objek penelitian.

\section{METODE PENELITIAN}

\subsection{Jenis dan Sumber Data}

Jenis data yang digunakan adalah data kualitatifdata-data yang tidak berwujud angka, berupa gambaran umum Entitas, struktur organisasi serta sistem dan prosedur. Sumber data yang digunakan dalam penelitian ini adalah data sekunder dalam penelitian ini adalah melalui buku-buku literatur, jurnal, serta bahan-bahan informasi lainnya yang berhubungan dengan materi yang dibahas oleh penulis. Data merupakan sekumpulan fakta atau fenomena yang dicatat melalui pengamatan langsung dan survei. Ketersediaan data merupakan satu hal yang mutlak dipenuhi dalam suatu penelitian.

\subsection{Metode Analisis Data}

Metode analisis dalam penelitian ini menggunakan metode analisis deskriptif. Dimulai dengan mengumpulkan dan menyaring keterangan-keterangan yang diperoleh secara menyeluruh dan detail, kemudian diuraikan sehingga diperoleh gambaran yang jelas. Adapun data yang diperoleh selanjutnya dilihat kesesuainnya dengan Peraturan Pemerintah yang berlaku dengan cara Menganalisis Perubahan Belanja Langsung dan tidak langsung pada Dokumen Perubahan Pelaksanaan Anggaran (DPA) tahun Anggaran 2016 dan Menganalisis laporan keuangan yaitu LRA Tahun anggaran

\section{HASIL ANALISIS DAN PEMBAHASAN \\ 4.1. Hasil Analisis \\ Analisis Dokumen Pelaksanaan Anggaran (DPA)}

Dalam Dokumen Pelaksanaan Anggaran (DPA) telah disusun untuk masing masing kegiatan baik kegiatan Rutin maupun kegiatan untukmasing masing Bidang-Bidang yang ada di Dinas Sosial Tenaga Kerja dan Transmigrasi kabupaten Minahasa Selatan untuk anggaran 2016. DPA juga disusun anggaran kas guna mengatur ketersediaan dana yang cukup untuk mendanai pengeluaran-pengeluaran sesuai dengan rencana penarikan dana yang tercantum dalam DPA Dinas Sosial Tenaga Kerja dan Transmigrasi kabupaten Minahasa Selatan. Dari hasil wawancara dengan Kepala Dinas Sosial Tenaga Kerja dan Transmigrasi kabupaten Minahasa Selatan selaku Pengguna Anggaran dan Bendahara Pengeluaran yang mengelola dana di dapat penjelasan bahwa, dalam pendanaan Dinas Sosial Tenaga Kerja dan Transmigrasi kabupaten Minahasa Selatan tersebut bersumber dari dana APBD.Dokumen Pelaksanaan Perubahan Anggaran(DPPA) Tahun 2016 Belanja Tidak Langsung dan Belanja Langsung pada SKPD Dinas Sosial Tenaga Kerja dan Transmigrasi Kabupaten Minahasa Selatan. Data dari Dinas Sosial Tenaga Kerja dan Transnigrasi Kabupaten Minahasa Selatan anggaran perubahan pada Dokumen Perubahan Pelaksanaan Anggaran (DPPA) Belanja Tidak Langsung yang sebelumnya dianggarkan sebesar 2.748.000.000,00 menjadi 2.597.381.250,00 atau mengalami pengurangan 5,48\% dari anggaran yang dianggarkan dan Belanja Langsung yang sebelumnya dianggarkan sebesar 2.177.735.575,00 menjadi 2.297.292.217,00 atau mengalami penambahan 5,49\% dari anggaran yang dianggarkan. Total Anggaran sebesar Rp. 4.894.673.476,00 yang terdiri dari belanja tidak langsung sebesar 2.597.381.250,00 dan belanja langsung sebesar 2.297.292.217,00. 


\section{Analisis Laporan Realisasi Belanja}

Dalam PSAP No.01 (10-11) Laporan Realisasi Anggaran mengungkapkan kegiatan keuangan PemerintahPusat/Daerah yang menunjukkan ketaatan terhadap APBN/APBD. Laporan Realisasi Anggaran menyajikan ikhtisar sumber, alokasi dan penggunaan sumber daya ekonomi yang dikelola oleh Pemerintah Pusat/Daerah dalam satu periode pelaporan. Laporan Realisasi Anggaran menggambarkan perbandingan antara Anggaran dengan Realisasinya dalam satu periode pelaporan. Data dari Dinas Sosial Tenaga Kerja dan Transmigrasi Kabupaten Minahasa Selatan Realisasi Anggaran pada Belanja tidak langsung adalah 2.577.126.659,00 dengan Anggaran 2.597.381.250,00 atau sekitar 99,22\% dari yang dianggarkan dan Belanja langsung adalah 2.256.160.490,00 dengan Anggaran 2.297.292.217,00 atau sekitar 98,21\% dari yang dianggarkan. Perubahan pada angka yang dianggarkan dan direalisasikan merupakan hal yang sering terjadi. Maka Belanja Langsung dan Tidak Langsung pada Dinas Sosial Tenaga Kerja dan Transmigrasi Kabupaten Minahasa Selatan sudah diakui, karena telah terjadi pengeluaran dari kas daerah dan telah direalisasi atau telah diterapkan dalam rincian dokumen perubahan anggaran belanja langsung dan tidak langsung pada Satuan Kerja Perangkat Daerah sudah berdasarkan PP No 71 Tahun 2010.

\subsection{Pembahasan}

\section{Analisis Dokumen Pelaksanaan Anggaran (DPA)}

Permendagri 13 Tahun 2006 Menjelaskan bahwa Dokumen Pelaksanaan Anggaran SKPD adalah Dokumen yang memuat pendapatan, belanja dan pembiayaan yang digunakan sebagai dasar pelaksanaan anggaran oleh pengguna anggaran. Dokumen perubahan pelaksanaan anggaran SKPD selanjutnya disingkat DPPA-SKPD Adalah Dokumen yang memuat perubahan pendapatan, belanja dan pembiayaan yang digunakan sebagai dasar pelaksanaan perubahan oleh pengguna anggaran.

Untuk penganggaran setiap program atau kegiatan hanya yang diusulkan oleh SKPD yang ada tercantum dalam Dokumen Pelaksanaan Anggaran (DPA).Pengalokasian untuk masing masing Program dalam DPA pada Dinas Sosial Tenaga Kerja dan Transmigrasi Kabupaten Minahasa Selatan sudah sesuai dengan proporsi yang telah ditetapkan pemerintah daerah.Anggaran Belanja Tidak Langsung dan Belanja Langsung pada DPA merupakan hal wajar yang sering terjadi saat penambahan atau pengurangan anggaran pada Satuan Kerja Perangkat Daerah.Sehingga untuk perencanaan anggaran yang ada di Dinas Sosial Tenaga Kerja dan Transmigrasi bisa dibilang baik dan transparan mengikuti aturan perundangundangan yang berlaku dan mendetail setiap anggaran yang ada. Dalam DPA ini juga merupakan acuan dalam pelaksanaan anggaran belanja langsung maupun belanja Tidak Langsung.

\section{Laporan Realisasi Anggaran Belanja}

PSAP No.01 (10-11) Laporan Realisasi Anggaran mengungkapkan kegiatan keuangan pemerintah pusat/daerah yang menunjukkan ketaatan terhadap APBN/APBD. Belanja daerah merupakan instrument penting dalam menjalankan roda pemerintahan. Untuk melaksanakan program dan kegiatan pemerintah diperlukan biaya atau pengeluaran. Dimana dana yang digunakan merupakan dana publik, sehingga dana tersebut harus digunakan secara efektif dan efisien agar besar alokasi dana yang dikeluarkan sesuai dengan kinerja akrual. Semua itu bisa tercapai apabila dana tersebut dikelola dengan baik dan benar.

Pengakuan belanja sesuai dengan PP No 71 tahun 2010 menyatakan belanja diakui saat terjadi pengeluaran dari rekening kas umum daerah untuk seluruh transaksi di satuan kerja perangkat daerah (SKPD). Pengakuan Belanja pada hal ini belanja langsung dan belanja tidak langsung pada dinas sosial tenaga kerja dan transmigrasi kabupaten minahasa selatan diakui pada saat terjadinya pengeluaran pada rekening kas umum daerah sudah sesuai dengan 
peraturan pemerintah no 71 tahun 2010 tentang standar akuntansi pemerintahan. Karena,Data realisasi pada Tabel di atas dapat dilihat belanja langsung dan tidak langsung pada dinas sosial tenaga kerja dan transmigrasi sudah terealisasi atau sudah dilaksanakan. Dengan demikian anggaran belanja pada dinas sosial tenaga kerja dan transmigrasi kabupaten minahasa selatan sudah keluar dari kas bendahara pengeluaran satuan kerja perangkat daerah.

Dalam melaksanakan dan menerapkan PP No. 71 Tahun 2010, dinas sosial tenaga kerja dan transmigrasi kabupaten minahasa selatan mempersiapkan SDM yang kompeten guna menghasilkan tata kelola keuangan daerah yang sesuai dengan peraturan yang berlaku, mengembangkan program aplikasi Sistem Informasi Manajemen Daerah (SIMDA) untuk mempermudah dan mempercepat prosespengelolaan dan pelaporan keuangan, serta mengadakan pelatihan bagi SDM di satuan kerja perangkat daerah. Dilihat dari kesiapan dinas sosial tenaga kerja dan transmigrasi kabupaten minahasa selatan dalam pelaksanaan sistem akuntansi belanja sudah sesuai dengan PP No 71 tahun 2010 dan tidak mengalami kendala sedikitpun. Hal ini menunjukkan kesiapan dari dinas sosial tenaga kerja dan transmigrasi kabupaten minahasa selatan dalam menerapkan standar akuntansi pemerintah berbasis Akrual sesuai peraturan pemerintah, yang diharapkan dapat menghasilkan laporan keuangan yang akuntabilitas dan transparansi.

\section{KESIMPULAN DAN SARAN}

\subsection{Kesimpulan}

Dokumen Pelaksanaan Anggaran pada Tahun 2016 pada Dinas Sosial Tenaga Kerja dan Transmigrasi Kabupaten Minahasa Selatan dalam penyusunannya sudah sesuai dengan peraturan dan standar-standar penyusunan yang berlaku serta sudah mendetail setiap anggaran yang ada. Dalam DPA ini juga merupakan acuan dalam pelaksanaan anggaran belanja langsung maupun belanja tidak langsung.Tahun Anggaran 2016 Dinas Sosial Tenaga Kerja Transmigrasi Kabupaten Minahasa Selatan Dalam Pelaksanaan Sistem Akuntansi Belanja sudah menerapkan atau sudah sesuai PP No 71 Tahun 2010 tentang Standar Akuntansi Pemerintah. Belanja pada Dinas Sosial Tenaga Kerja dan Transmigrasi Kabupaten Minahasa Selatan yang direalisasi atau diterapkan sudah diakui pada saat keluarnya Anggaran Dari Kas Bendahara Satuan Kerja Perangkat Daerah.

\subsection{Saran}

Bagi Dinas Sosial Tenaga Kerja dan Transmigrasi Kabupaten Minahasa Selatan sebaiknya tetap mengawasi dan mengevaluasi laporan Realisasi Anggaran Belanja, sehingga pemborosan pengeluaran dapat diminimalkan serta selalu mengacu pada pada Peraturan Pemerintah yang berlaku agar pengelolaan keuangan menjadi efektif dan efisien sesuai yang diharapkan.

\section{DAFTAR PUSTAKA}

Abraham Oni, Akbonkhese. 2014. Impact of public expenditure on the growth of nigerian economy. European Scientific Journal October 2014bedition vol.10.no.28 ISSN: 18577881 (Print) e-ISSN 1857-7431.

Egbetunde, Tajudeen. 2013. public expenditure and economic growth in nigeria: evidence from auto-regressive distributed lag specification. Zaggreb international Review of Economics \& Business. Vol.16, no.1, pp. 79-92. 2013

Halim, Abdul. Kusufi Muhammad syam. 2014. Teori, konsep, dan Aplikasia kuntans I sektor publik. Jakarta, salemba Empat.

Kiaydemak, Dedy. 2015. Penerapan PP 71 tahun 2010 dalam pelaporan Akuntansi belanja dinas pekerjaan umum kota kotamobagu tahun anggaran 2014. Fakultas Ekonomi dan 
Bisnis Jurusan Akuntansi Universitas Sam Ratulangi Manado.Jurnal EMBA Vol 4 No. 1

Londong,Arlika.2013.Evaluasi Prosedur Pengeluaran Kas Belanja Langsung Pada Dinas Kebersihan Kota Bitung. Fakultas Ekonomi dan Bisnis Jurusan Akuntansi Universitas Sam Ratulangi Manado. Jurnal EMBA ISSN 2303-1174 Vol 3 No. 1

Mahsun, Mohamad, Firma Sulistiyowati, Heribertus dan A. Purwonugroho. 2011. Akuntansi Sektor Publik. EdisiKetiga. BPFE, Yogyakarta

Maryam, Sitti. 2011. Evaluasi Penerapan Akuntansi Belanja Modal Berdasarkan Peraturan Pemerintah No. 71 Tahun 2010 pada Dinas pekerjaan Umum Kota Manado. Skripsi. Universitas Sam Ratulangi Manado

Nugroho, D.Riant. 2007. Analisis Kebijakan. PT. Elex Media Komputindo, Jakarta.

Pemerintah Republik Indonesia. 2010. Peraturan Pemerintah Nomor 71 Tahun 2010 tentang Standar Akuntansi Pemerintah, Jakarta.

Pemerintah Republik Indonesia. 2011. Peraturan Menteri Dalam Negeri Nomor 21 Tahun 2011 tentang Pedoman Pengelolaan Keuangan Daerah, Jakarta.

Pandoh, Gabriela. 2016. Evaluasi system pencatatan langsung pada dinas pekerjaan umum kabupaten minahasa tenggara. Fakultas Ekonomi dan bisnis jurusan Akuntansi Universitas Sam ratulangimanado. Jurnal EMBA Vol 4 No. 1

Pontoh, Winston. 2013. Akuntansi Konsep dan Aplikasi. Halaman Moeka. Jakarta

Retno Sundari, 2013, “Analisis Belanja Langsung Pada Dinas Kesehatan kabupaten klaten. Universitas Muhammadiyah Surakarta.

Singgima, Febrian. 2016. Evaluasi Prosedur Pengeluaran Kas Belanja Langsung pada Dinas Pendidikan Provinsi Sulawesi Utara. Fakultas Ekonomi dan Bisnis Jurusan Akuntansi Universitas Sam Ratulangi Manado. Jurnal EMBA Vol 4 No. 1

Winarno, Kurniawan. 2016. Evaluasi penerapan Akuntansi belanja modal berdasarkan peraturan pemerintah nomor 71 tahun 2010 pada dinas pendidikan nasional provinsi Sulawesi utara. Fakultas Ekonomi dan Bisnis Jurusan Akuntansi Universitas Sam Ratulangi Manado. Jurnal EMBA Vol 4 No. 1 